\title{
The White Volcanoes of Harrat Khaybar, north of Al-Madinah
}

\author{
Michael A. Kaminski ${ }^{1,2}$, Abdulaziz Al Shaibani ${ }^{1}$, Khalid Al Ramadan ${ }^{1}$ \\ ${ }^{1}$ Earth Sciences Department, King Fahd University of Petroleum \& Minerals, PO Box 701, Dhahran 31261, Saudi Arabia \\ ${ }^{2}$ AGH University of Science and Technology, Faculty of Geology, Geophysics and Environmental Protection, \\ al. Mickiewicza 30, 30-059 Kraków: \\ e-mail:kaminski@kfupm.edu.sa,shaibani@kfupm.edu.sa,ramadank@kfupm.edu.sa
}

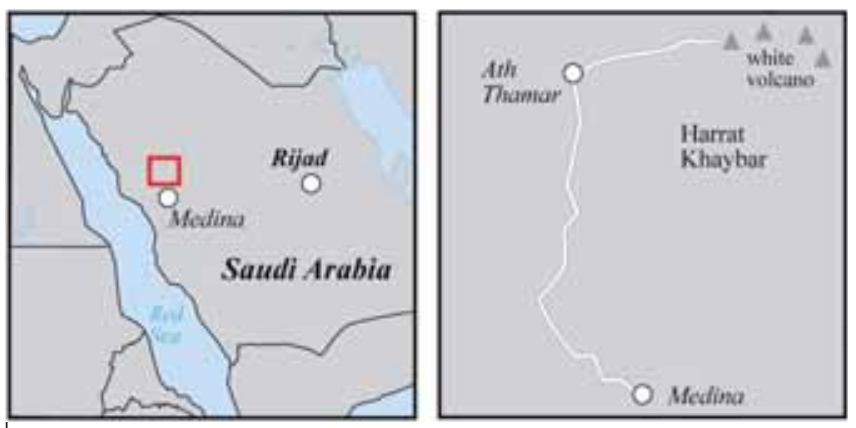

Abstract: The volcanic field of Harrat Khaybar north of Al-Madinah, Saudi Arabia contains rare examples of white volcanoes comprised mainly of the felsic rock comendite. The obsidian that occurs in association with the white comendite was exploited and worked by Neolithic inhabitants of the area. The white volcanoes are surrounded by more recent black basaltic lava fields that follow the pre-existing topography and display both a and pahoehoe flow structures. Although situated only $60 \mathrm{~km}$ from a busy motorway, the volcanic area is remote and all necessary safety precautions must be taken in order to visit the volcanoes.

Key words: White Volcano, Harrat, lava field, basalt, comendite, Saudi Arabia

\section{Introduction}

Each year millions of pilgrims from all over the world make a visit to the city of Al-Madinah in Saudi Arabia (also known as Medina in the western literature) to view its many holy sites and pray in the Prophet's Mosque, which holds the tomb of the Prophet Mohammed. Few pilgrims, however, realize that the area surrounding Al-Madinah hosts a variety of interesting geological features that are also of worldwide significance - the foremost among them being the "White Volcanoes of Harrat Khaybar". A hundred years ago, the adventurous European traveler would have been able to make the journey in luxury on board the Orient Express from Vienna, change trains in Istanbul to a Turkish Railways train to Damascus, then transfer onto the Turkish-run Hijaz Railway to Al-Madinah. From his seat in the railway carriage, the traveller would have been offered a view of the volcanic peaks of Harrat Khaybar on both the eastern and western horizons as he approached Al-Madinah. Although situated in what to this day remains a remote area, a visit to the white volcanoes will reward the visitor with textbook examples of volcanic features that all geologists have learned in their elementary geology courses.
The volcanic fields of the Arabian shield, called "Harrat" in Arabic, are the surface expressions of volcanism that is associated with the opening of the Red Sea in Oligocene to Recent times. The last recorded volcanic eruption in the Al-Madinah area took place in 1256 , but the oral history of local residents suggests that some volcanic activity is much more recent - as young as $18^{\text {th }}$ or early $19^{\text {th }}$ century (Grainger, 2007). The vast majority of volcanoes around the Red Sea produce normal basaltic lava, but a few of them are very different - spewing out rocks and ash that are more similar in composition to that of continental crust. Volcanoes such as these are known from the African Rift Valley in Tanzania and Kenya, where subsurface volcanism melts continental crustal rocks. Rare examples of such volcanoes on the Arabian Peninsula are the Jabal al Abyad and its neighbour Jabal Bayda (the two Arabic words Abyad and Bayda both mean "white") - the white volcanoes of Khaybar.

\section{Geology \& geotourism}

Our journey begins at Al-Madinah Airport, which is served by international airlines. A four-wheel drive vehicle will be essential, preferably one of the popular white pickup trucks that are so commonly used by people who live outside the cities and towns in Saudi Arabia. Take the airport Road to the Ring Road and proceed west until the junction with Highway 15 (Fig. 1). The south side of the Ring Road is the boundary of the "Haram" or "Forbidden area" of central Al-Madinah, where access is restricted to followers of the Islamic Faith. The boundary of the Haram area is marked by large white illuminated signs. Accommodation (rental apartments or 4 to 5 star hotels) can be found along the north side of the Ring Road, adjacent to a large petrol station a short distance past the intersection with Highway 15.

The road to the white volcanoes begins at the Highway 15 junction. Proceed north along Highway 15 for a distance of about $140 \mathrm{~km}$ to the town of Ath Thamad, which is an oasis of date farms. Approaching the town from the south, the roadcuts along Highway 15 first expose pastel-coloured Precambrian metamorphic rocks, and then after some distance we enter the volcanic Harrat. Here the roadcuts expose flat-lying columnar-jointed basalt, which in places is seen to overlie a reddish lateritic soil. As we approach the town, some jagged volcanic peaks are visible in the distance on the righthand side of the road. This mountainous area is our ultimate destination (Fig. 2). 


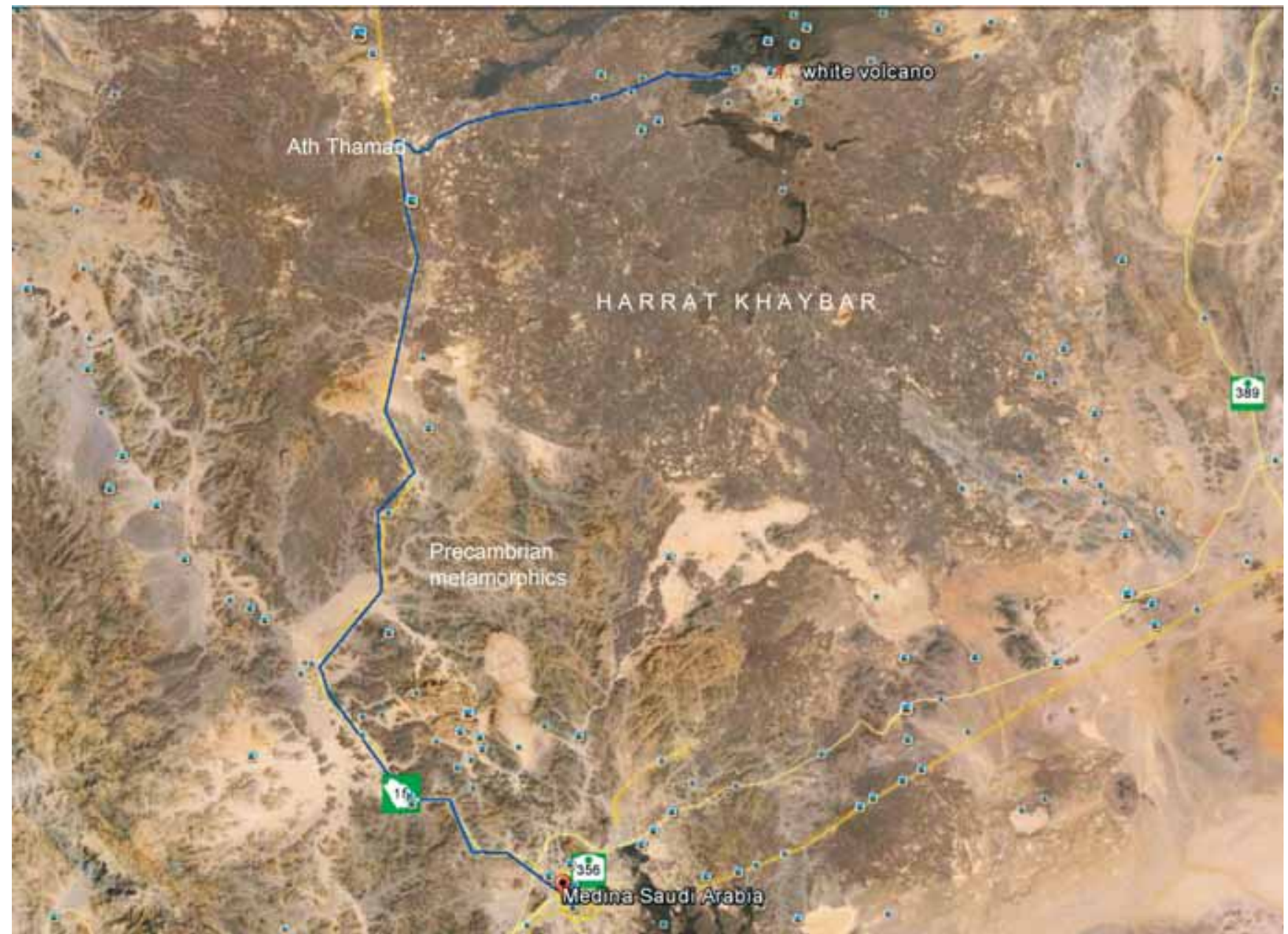

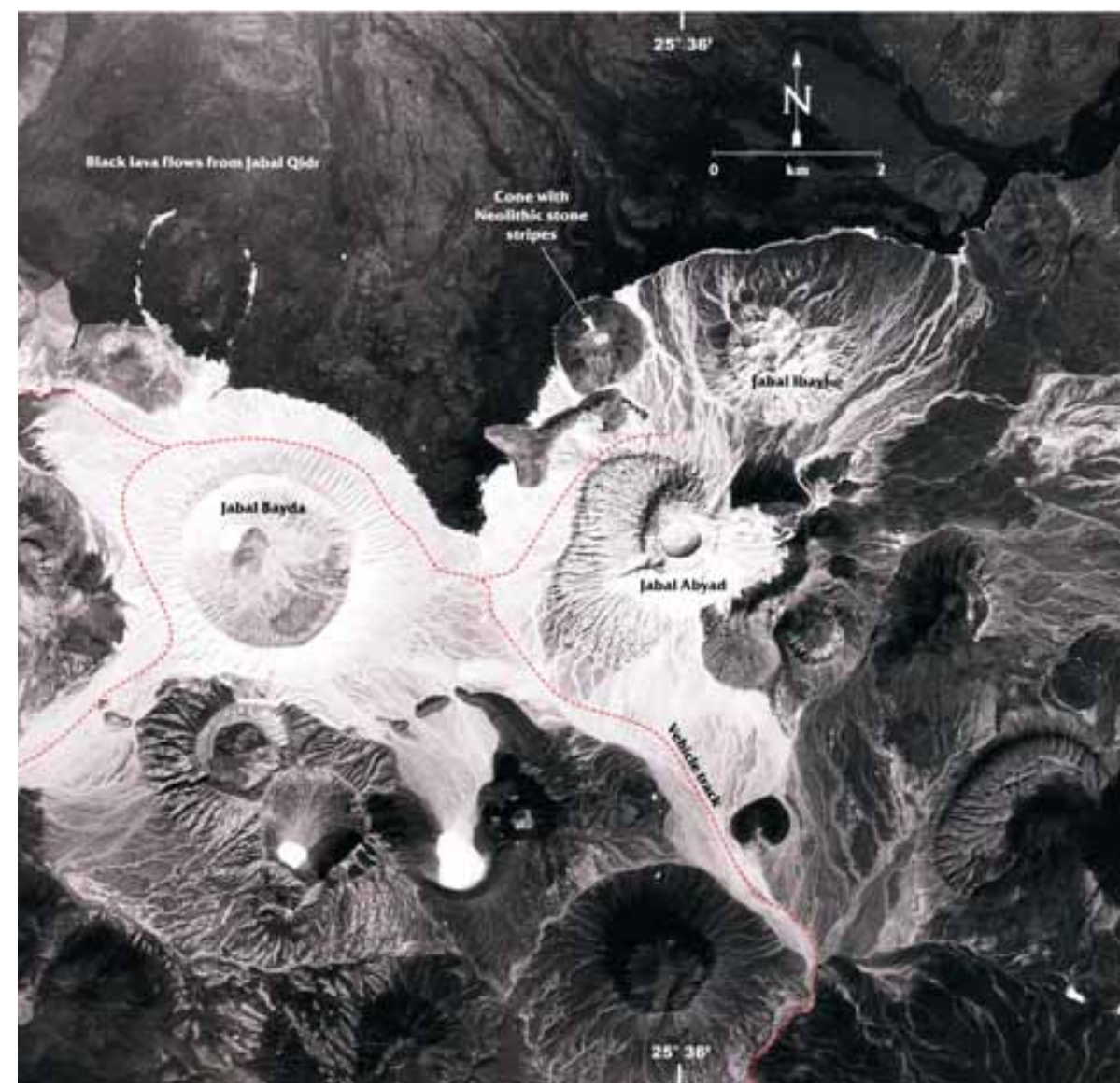

Fig. 1. Google Earth image of the area north of Al-Madinah, showing the areal extent of the volcanic Harrat Khaybar with the white and black volcanoes, photo M. Kamiński

Fig. 2. Areal photograph of the white volcanoes showing vehicle track (copyright by Saudi Geological Survey)

In Ath Thamad, our journey takes us past the date farms on the righthand side of Highway 15, to a road junction that is signposted "Jabal al Abyad" (Fig. 3). About $50 \mathrm{~m}$ past this road junction on the right is a large petrol station, which provides the last opportunity to buy fuel, food, and water before heading out into the mountains. The white volcanoes are located another $60 \mathrm{~km}$ away from this intersection, and the visitor is advised to top up the fuel tank, purchase enough essential supplies, and check the spare tyre of the vehicle to ensure that it is functional. The use of a second vehicle for the trip is advised. 


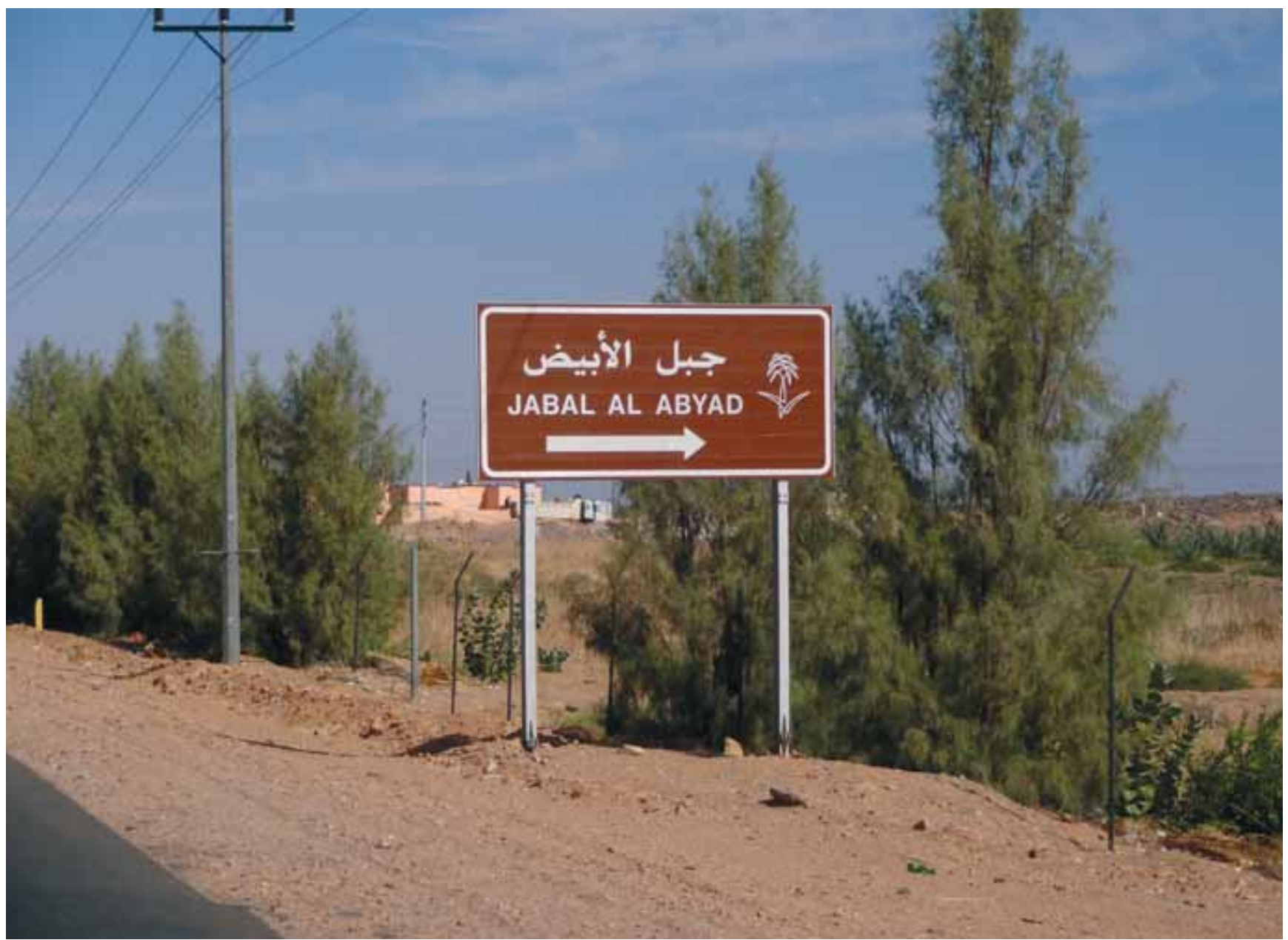

Fig. 3. Road sign on Highway 15 (North) indicating the turn-off for the white volcanoes, photo M. Kamiński

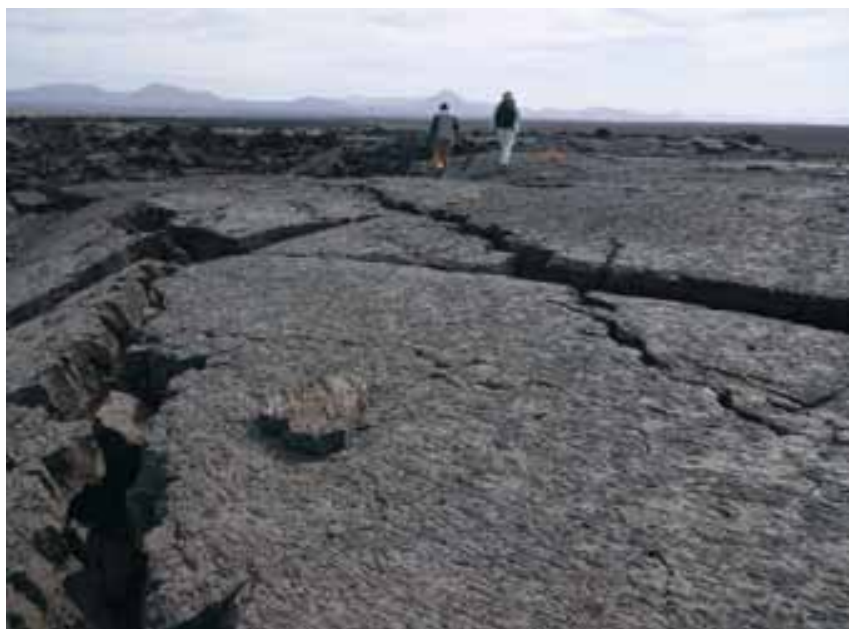

Fig. 4. Glassy surface of a lava flow that meets the main road, $55 \mathrm{~km}$ east of Highway 15, photo M. Kamiński

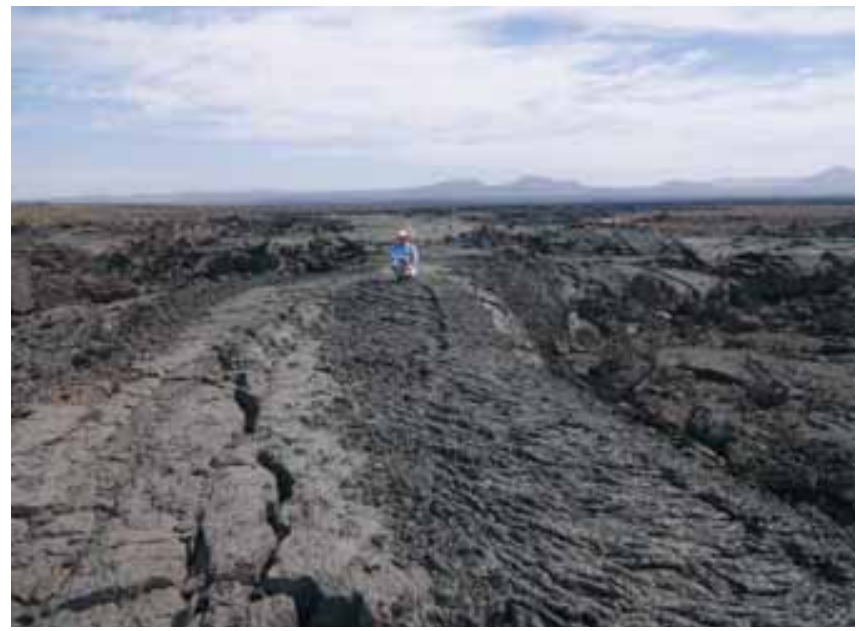

Fig. 5. A frozen "stream" of pahoehoe lava, same locality as Figure 2, photo M. Kamiński
The trip to the white volcanoes occupies the better part of a morning, so if the intention is to spend any time exploring the area, the visitor needs to take along a camping tent and sleeping bag, as no facilities of any kind are available on site.

The main road to the area of the white volcanoes is newly reconstructed and resurfaced, so access to the volcanic area is much better than what has been described previously.
Proceed on the "Jabal al Abyad road" past some houses and small farms, and continue driving for a distance of $55 \mathrm{~km}$ past fields of volcanic boulders. At this point (N25 $42.50^{\prime}$; E39 ${ }^{\circ}$ 47.96') the new road passes through some obvious volcanic features, including vesicular basalt exposed in the roadcut, behind which lies a fresh lava flow with a glassy surface, and clear flow structures (Figs 4, 5). 


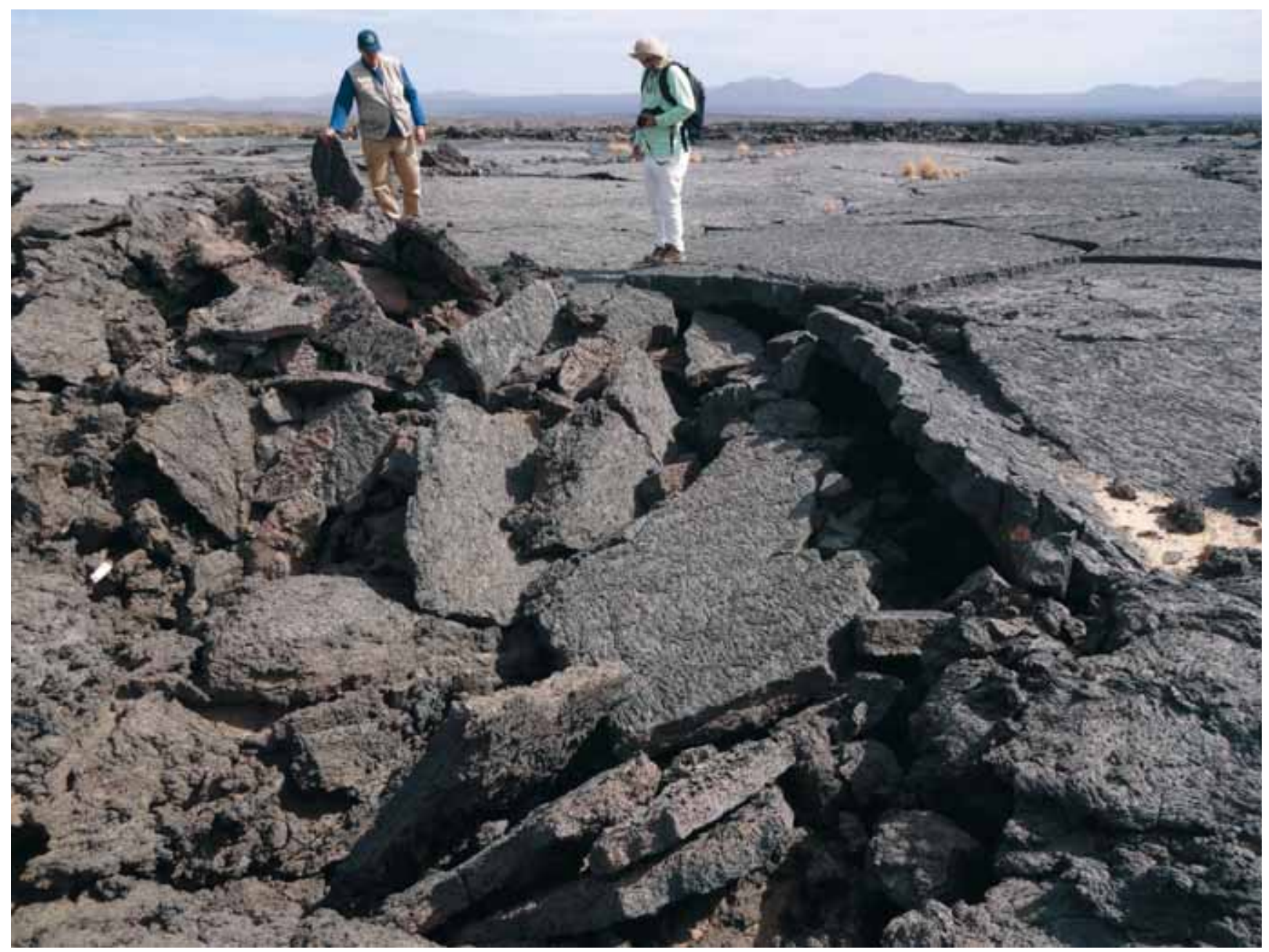

Fig. 6. Collapsed surface of the lava tube, photo M. Kamiński

A short stroll along the surface of the lava flow reveals that it is in fact a lava tube, with collapsed "sinkholes" present in places (Fig. 6). The lava flow generally followed the pre-existing topography. At this locality, the white volcanoes become visible in the distance. The distinctive eroded shape of the cream-coloured Jabal al Abyad has been rightfully described as resembling that of a jellyfish. The paved road now continues uphill for a short distance, eventually reaching a track that passes a couple of farms surrounded by earthen (volcanic cinder) enclosures. Follow this track around to the right of the farms and continue around the side of the volcanic cinder cone. At this locality the desert pavement consists of loose, pea-sized, dark grey volcanic lapilli derived from the cinder cone (Fig. 7).

The track leads around the mountain to small overlook that is frequented by people with dune buggies, judging from the numerous vehicle tracks on the sides of the cinder cone. From

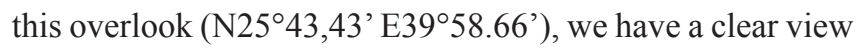
of Jabal al Bayda and Jabal al Abyad (both words meaning "white mountain" in Arabic) in the distance, with a black sea of fresh lava flows in the foreground. From this point the track leads down the cinder cone and bears left, mostly bypassing this impressive "sea" of jagged black lava. The track leading around the lava field to the white volcanoes is visible in the distance (Figs 8, 9).
Proceeding down the hill along the track, continue until the track reaches the lava flow on the right-hand side. The basaltic lava flow forms a wall of sharp, inky black, glassy slabs of rock, some of which stand erect as sentinels (Fig. 10).

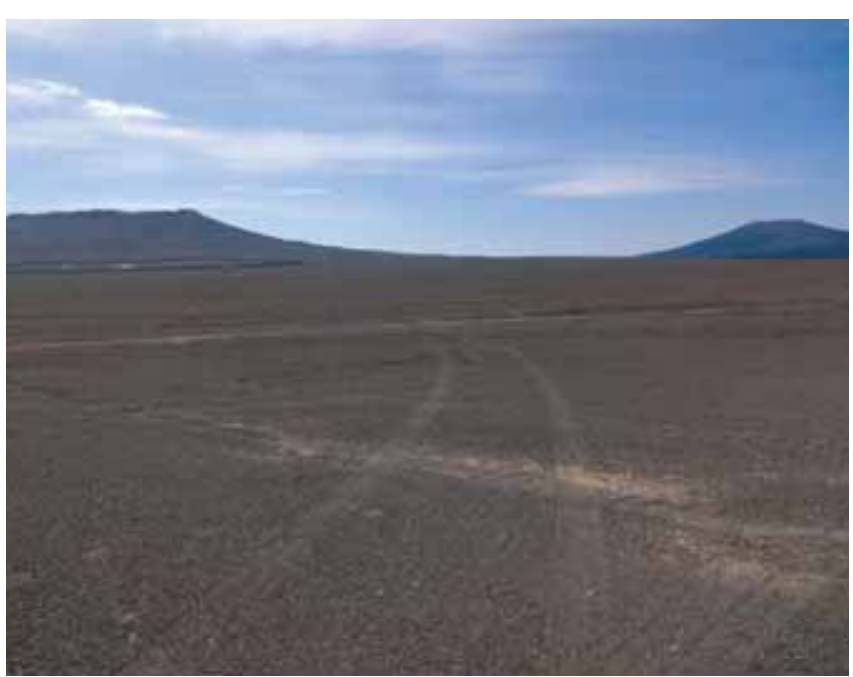

Fig. 7. Lapilli-paved surface of the desert, at the turn-off from the main road. The track leads around the enclosed farm to the cinder cone in the distance, photo M. Kamiński 


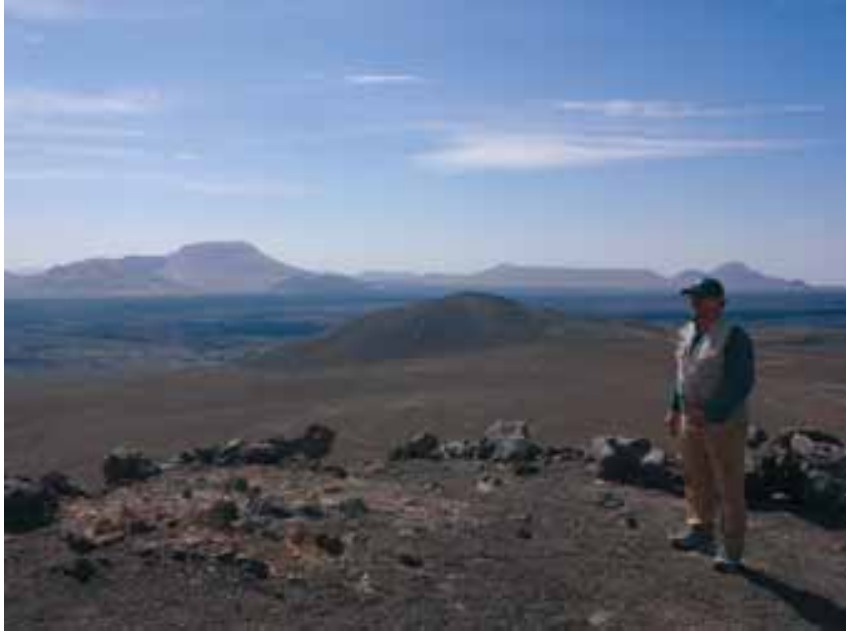

Fig. 8. View toward the white volcanoes from the far side of the cinder cone. Jellyfish-shaped Jabal al Abayda is on the left, the lower broader cone of Jabal al Bayda is in the far distance. A sea of more recent black lava is seen in the middle foreground, photo M. Kamiński

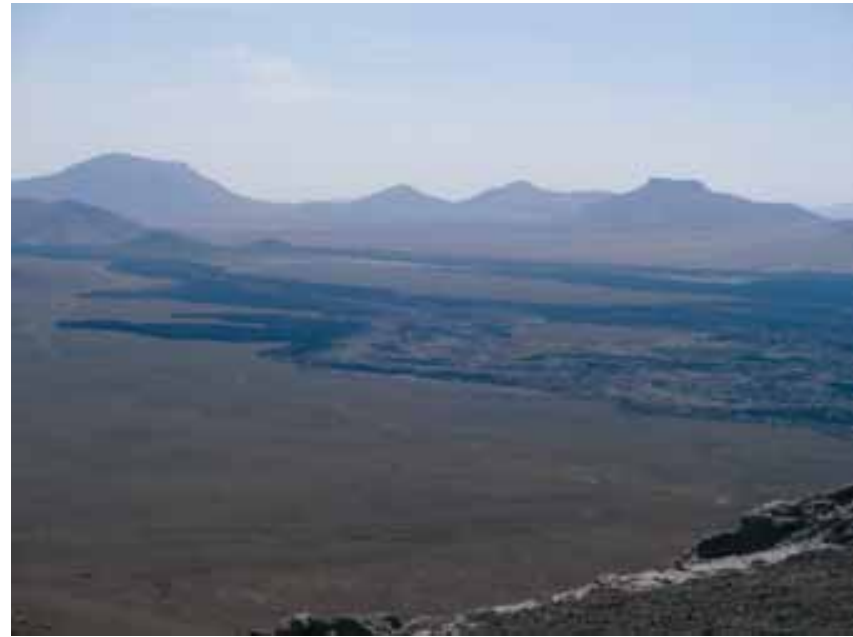

Fig. 9. Basaltic lava field emanating from Jabal Qidr, with the track visible to the front and left of the flows, photo M. Kamiński

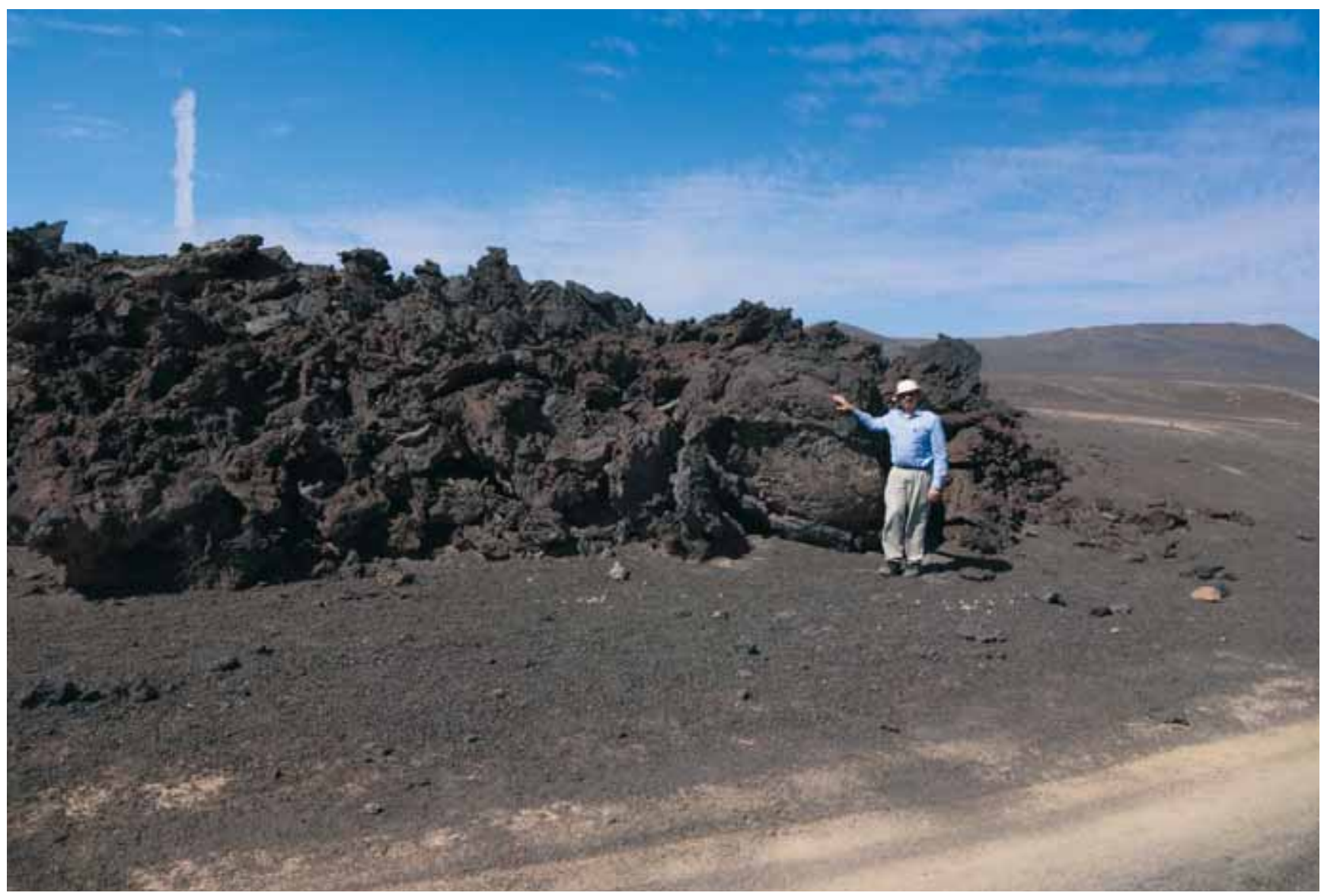

Fig. 10. The face of an aa lava tongue, along the track to the white volcanoes, photo A. Al Shaibani

This type of lava flow that consists of brecciated, sharp broken slabs and fragments of rock is termed "aa" lava (pronounced $\mathrm{Ah}-\mathrm{Ah}$ ). The word is borrowed from the Polynesian Hawaiian language, and is possibly derived from the cries of pain that would be emitted by a barefoot traveller as he crosses such a lava flow. The track crosses through the "aa" lava flow, and proceeds through a lapilli field to the next lava flow.
This lava flow has a smooth, glassy surface, and the path over the flow is indicated by stone markers (Fig. 11). However, it is advisable to exit the vehicle and survey the path over the lava flow on foot, removing any sharp stones from the track before attempting to cross it. A hundred meters to the left of the track, the "aa" flow we crossed previously is seen to be superimposed on top of this glassy lava flow (Fig. 12). 


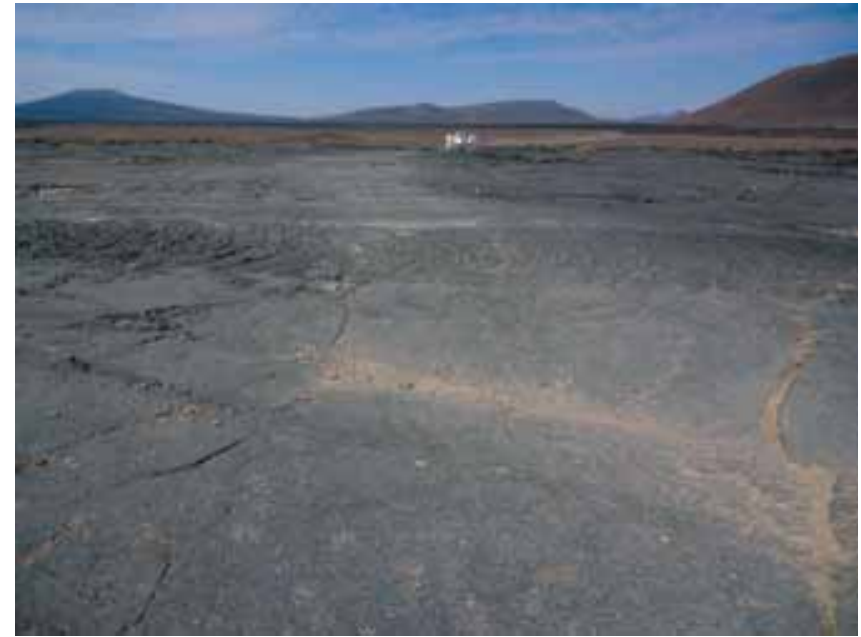

Fig. 11. The track crossing the surface of a pahoehoe lava flow, photo M. Kamiński

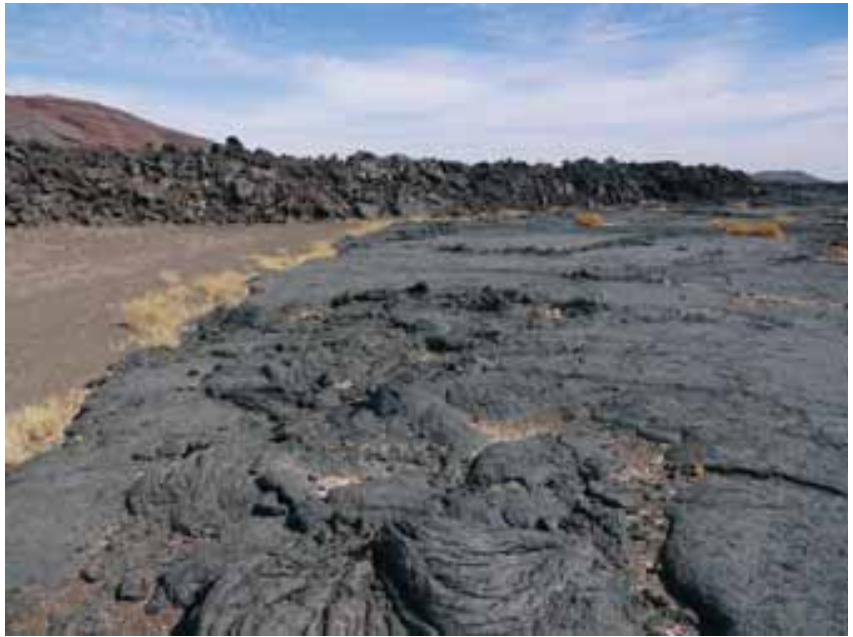

Fig. 12. A blocky aa lava flow superimposed onto the pahoehoe flow, photo M. Kamiński

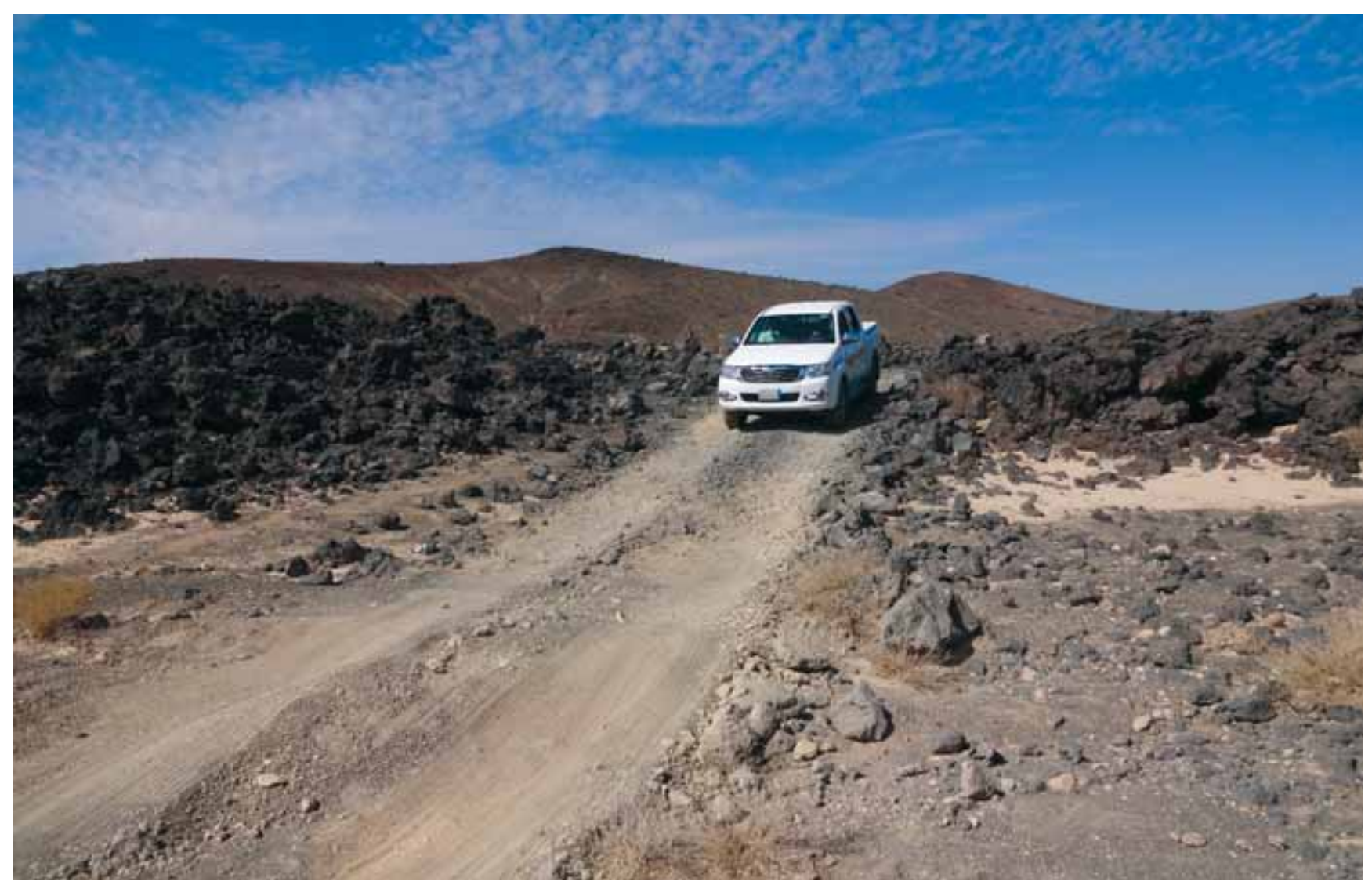

Fig. 13. Exiting the last a lava flow onto desert alluvium derived from the white volcanoes, photo M. Kamiński

Crossing over the track, we observe that in places the top surface of the flow has a "ropy" texture that is caused when the congealing surface crust of the flowing lava is deformed by the flow of a hotter, more fluid lava beneath. As a result of the movement of the lava, the surface crust (or "koziuch") of the lava is twisted into shapes that resemble curved coils of rope. Such a texture is called "pahoehoe" lava by the Polynesian Hawaiians. Whether a particular lava flow forms an "aa" or "pahoehoe" flow is a function of the composition of the lava as well as its temperature and viscosity.
After crossing the pahoehoe lava flow with its impressive surface crust, the track continues through a lapilli field and circumnavigates the lava flows on the right-hand side. We begin to see increasingly better views of the white volcanoes in the middle distance. Eventually the track crosses another aa lava flow, which is the final impediment along the way to the volcanoes (Fig. 13). Again, the track over the lava flow should be surveyed on foot before attempting to cross it.

Now the colour of the volcanic rock comprising the desert pavement becomes lighter. We pass a volcanic cone made 
of rocks the colour of creamy milk chocolate, and the track then climbs a chocolate-coloured hill, the top of which offers a spectacular view of the white volcanoes Jabal al Abyad $(2,093 \mathrm{~m})$ and Jebel Bayda $(1,913 \mathrm{~m})$ as well as the sea of recent black lava that flowed out more recently from flat-topped Jabal Qidr (2,022 m), visible on the western horizon (Fig. 14).

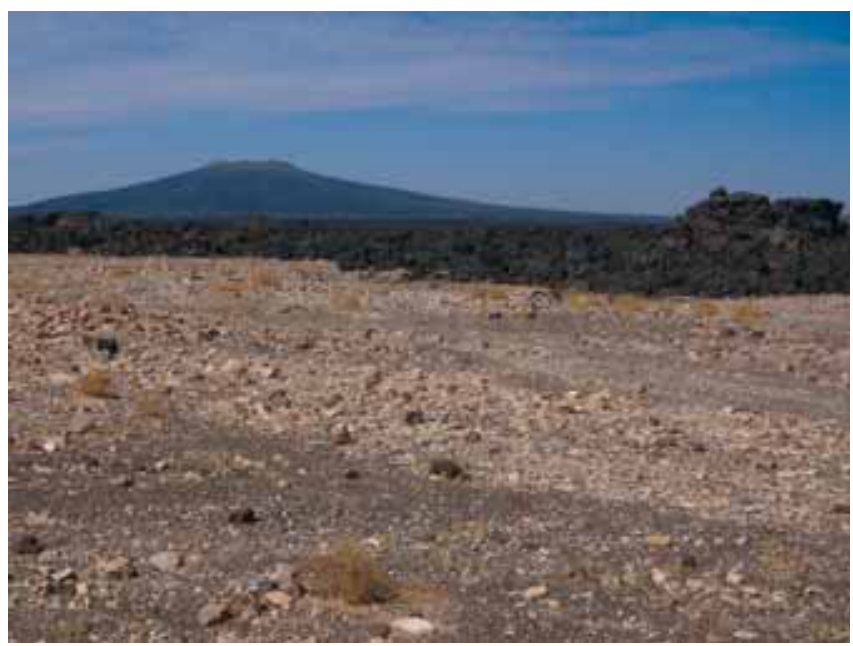

Fig. 14. View toward Jabal Qidr, with the sea of black lava in the middle foreground, photo M. Kamiński
Following the track down the hill in the direction of Jabal al Abyad (Figs 15, 16), we see the relative stratigraphy of the various volcanic units, the white ash of Jabal Bayda, the light brown pyroclastics from Jabal al Abyad, and finally the black lavas of Jabal Qidr onlapping onto the alluvium derived from the white volcanoes.

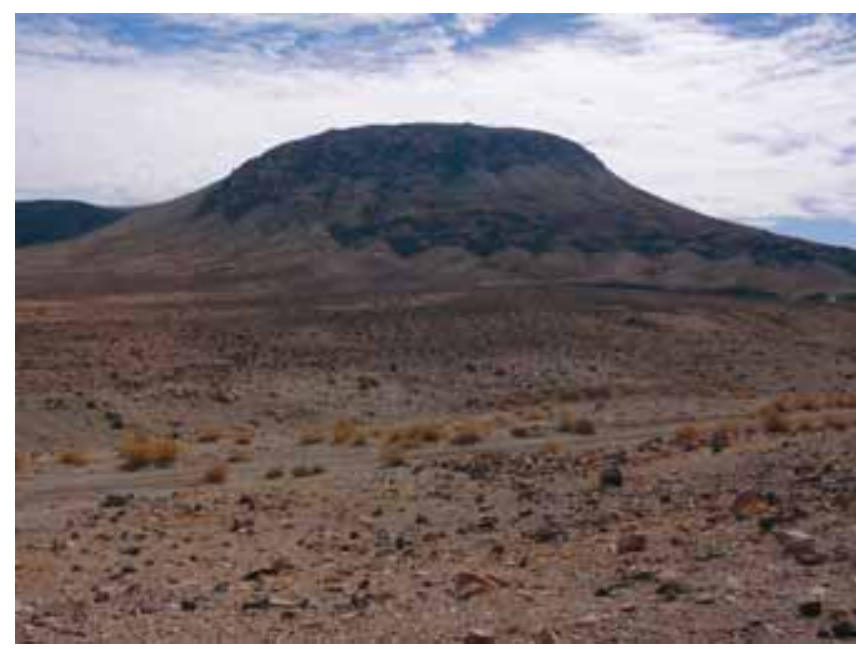

Fig. 15. Jabal al Abyad, with light-coloured desert pavement in the foreground, photo M. Kamiński

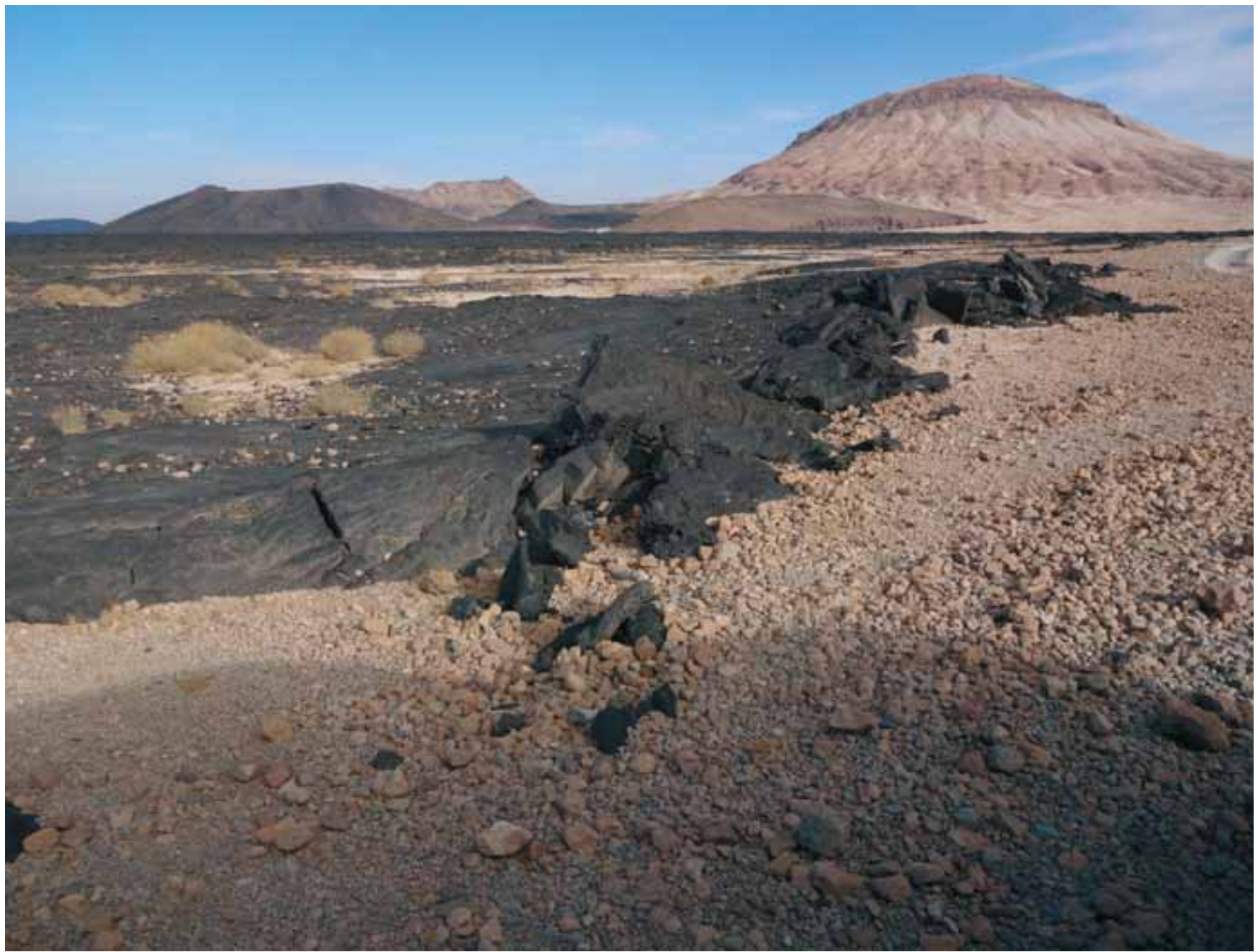

Fig. 16. View of Jabal al Abyad from the south, with the edge of the basaltic lava field in the center and left, photo M. Kamiński 


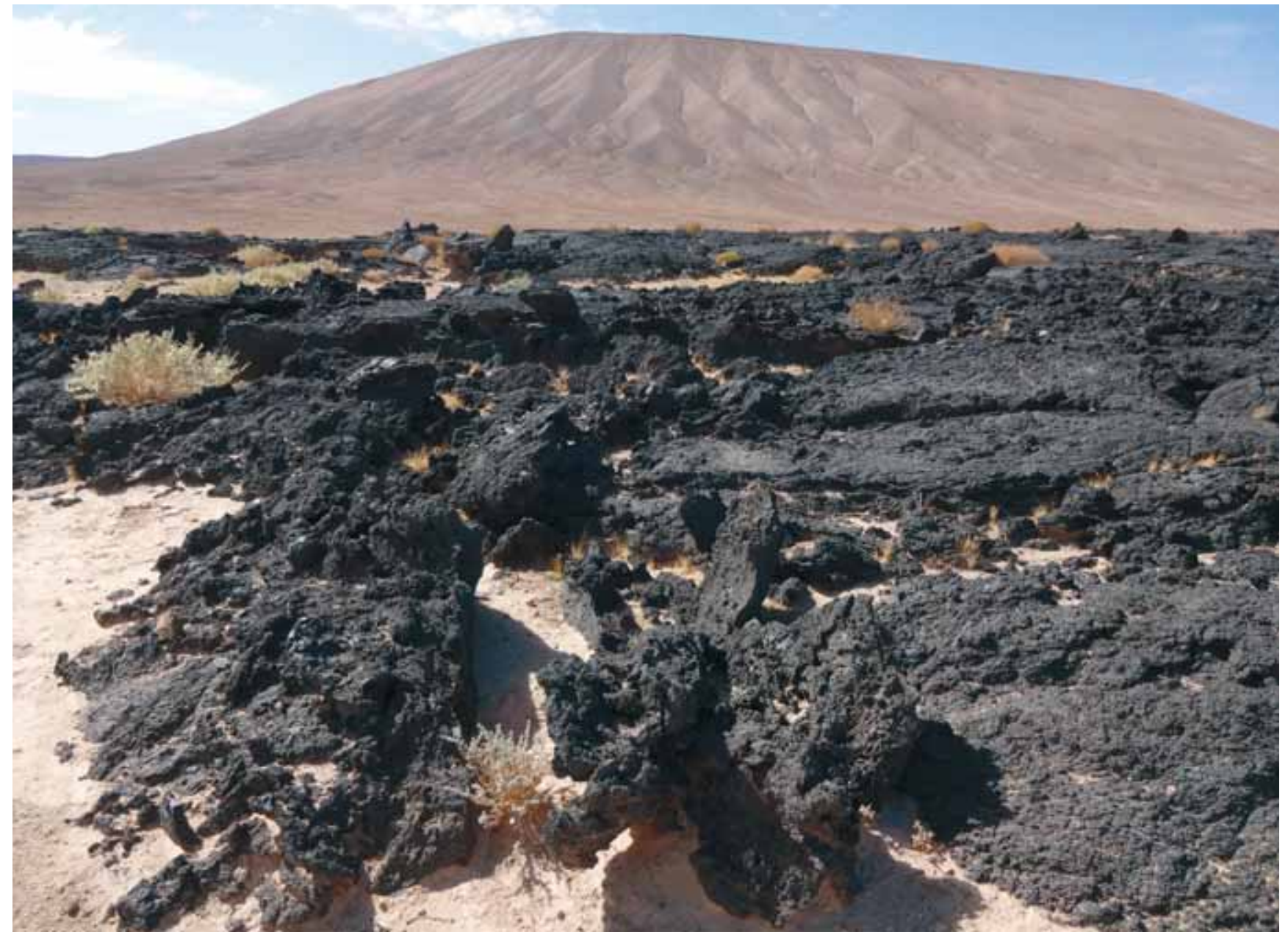

Fig. 17. View of Jabal al Bayda from the north, with black lava from Jabal Qidr at its base, photo M. Kamiński

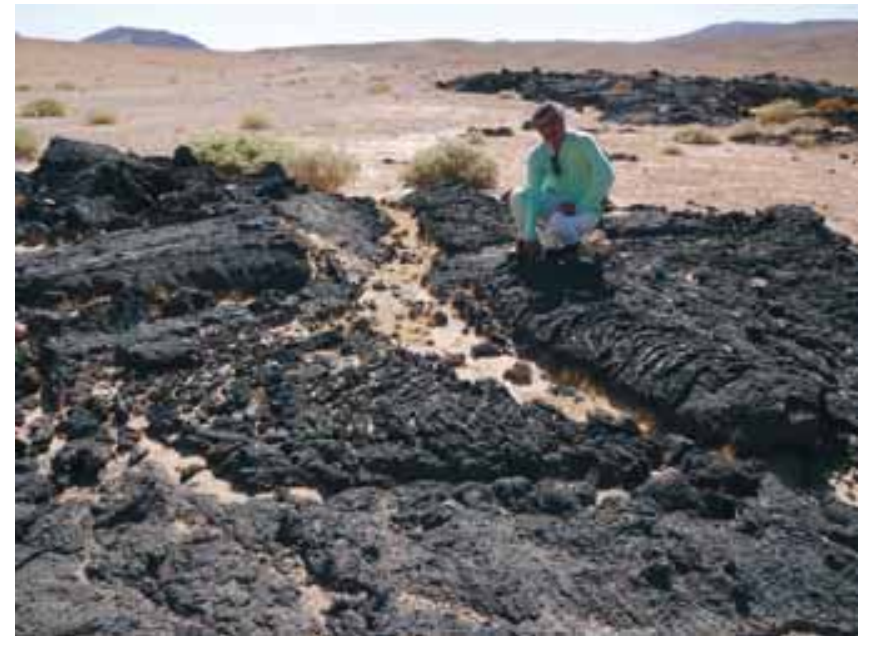

Fig. 18. Pahoehoe lava structures at the edge of the lava flow, photo M. Kamiński

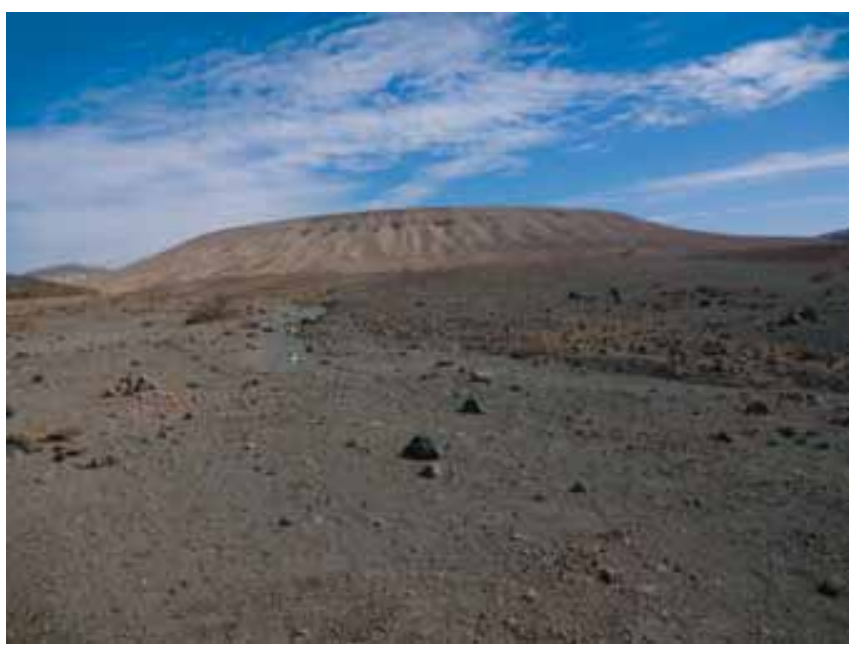

Fig. 19. View of Jabal al Bayda from the southwest, photo M. Kamiński
The track now proceeds along the base of Jabal Bayda, keeping the black lava sea on the right side of the track (Figs 17, 18). The rock comprising the cone of Jebel Bayda is classified as comendite, which mainly consists of quartz and albite phenocrysts in a fine groundmass. The rock feels surprisingly light when picked up - almost pumice-like. It is white (or very light grey) in colour when fresh and weathers to a medium grey or creamy grey colour. This silica-rich volcanic rock type is quite rare, and is known from localities in East Africa. The magma that formed the comendite was highly viscous and contained volatiles. As a result, the eruptions of such volcanoes are explosive and produce mostly rock fragments 
and volcanic ash. A short scramble up the scree slope comprising the flanks of Jabal Bayda will offer a view of its $1.5 \mathrm{~km}$ wide central crater (Figs 19, 20). The center of the crater holds a small cinder cone created by its most recent eruption.

In addition to comendite, the silica-rich volcanoes also produced a dark grey volcanic glass called obsidian, which was highly prized by Neolithic tool makers. This obsidian was mined by Neolithic residents in quarries that are still visible on the eastern side of the Jabal Abyad, and obsidian artifacts have been found throughout the Harrat Khaybar area (Grainger, 2007). A fine collection of obsidian tools and other artifacts can be seen on display in the Saudi National Museum in Riyadh. It is thought that during Neolithic times, the area around Jabal Bayda was more suitable for human habitation, and traces of Neolithic structures (low walls of basaltic stones) can still be seen in the area, as well as ancient (pre-Islamic) petroglyphs carved into the desert lacquer of the larger stones. It is believed that some of the stone markings identified the people or tribes that laid claim to the area currounding the obsidian quarries.
Continuing along the track that leads around the base of Jabal Bayda, we pass the basaltic lava field, and then on the southern side of the volcano, the track leads up to a saddle between Jabal Bayda on the left, and a darker volcanic cone on the right. From the top of the saddle between the two volcanoes, another track branches off to the left that leads to the rim of the crater. However, in the interest of safety, the last part of this journey is best done on foot.

From this high point, the track leads down the opposite side of Jabal Bayda, around the darker volcano, and down into a wadi (the Arabic word for "gully") that is paved with light-coloured alluvium from Jabal Bayda. At this location, the visitor is surrounded by volcanic features. At one point along the wadi, we see a stream of black lava that seems to have overspilled from the lava field, and ran down the side of the wadi like some molten stream of dark chocolate (Fig. 21). At another point along the wadi ( $25^{\circ}, 40.45^{\prime}$, E39 $\left.9^{\circ} 55.38^{\prime}\right)$, igneous intrusions on the flanks of the volcano show textbook examples of columnar jointing (Figs 22, 23) - though the columns are much smaller than those seen in roadcuts along Highway 15.

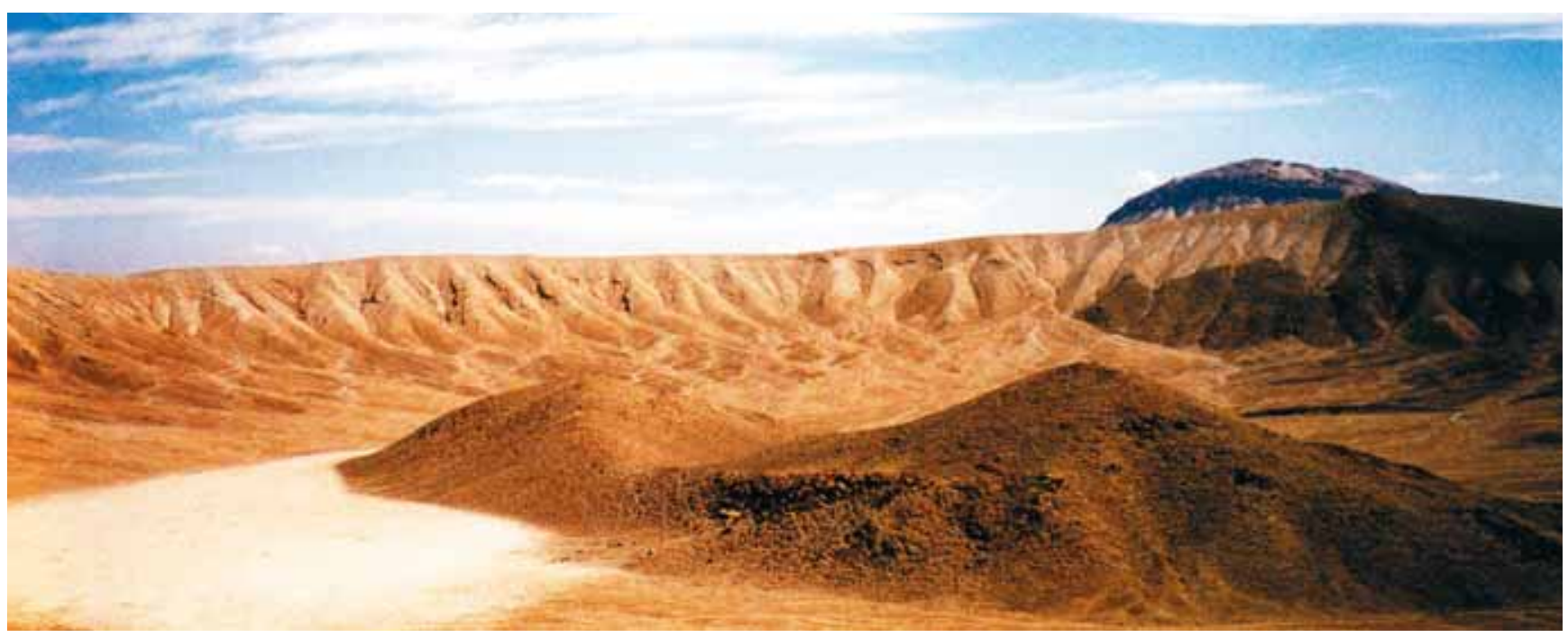

Fig. 20. View into the crater of Jabal al Bayda, showing the smaller cinder cone in its centre. The top of Jabal Qidr is visible in the distance, photo D. Grainger

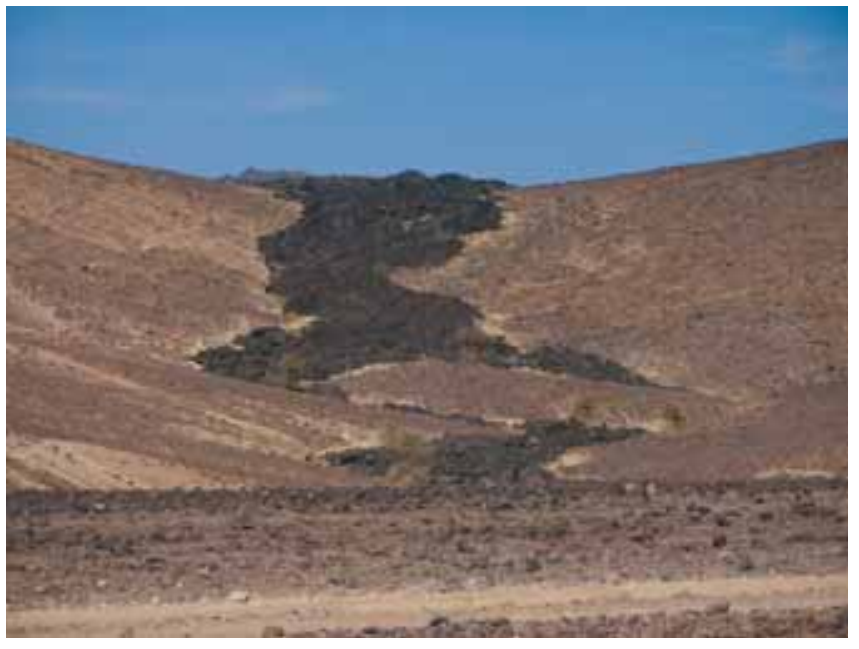

Fig. 21. A stream of lava which overspilled into the wadi SE of Jabal al Bayda, photo M. Kamiński

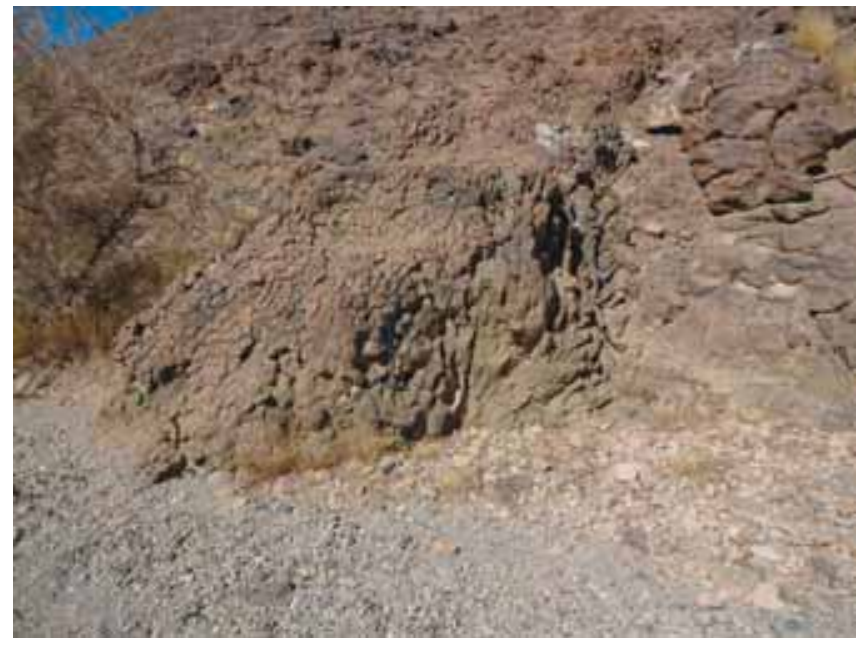

Fig. 22. A dyke of basaltic lava showing small-scale columnar jointing, photo M. Kamiński 


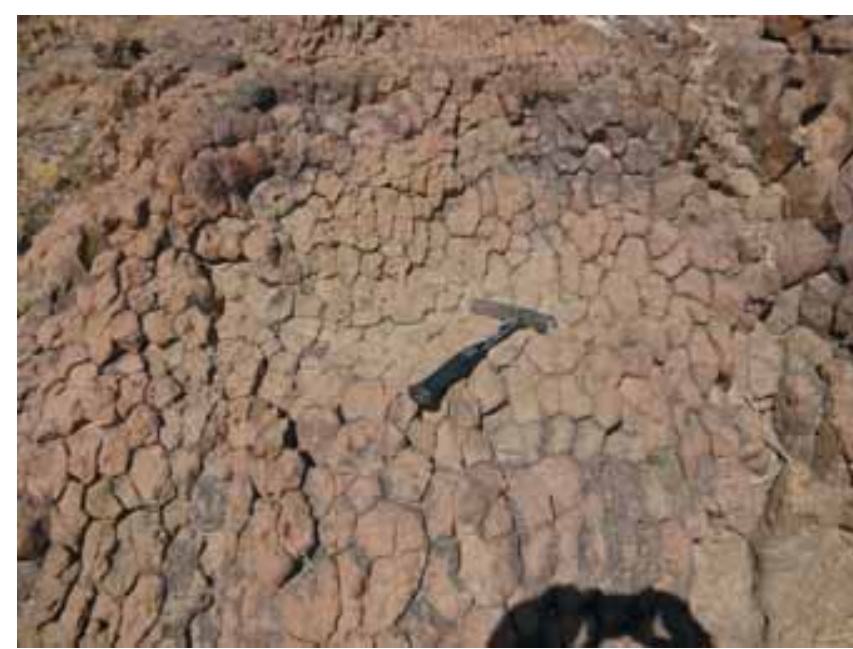

Fig. 23. Detail of Figure 22. Hammer for scale, photo M. Kamiński

From this point, the desert tracks bifurcate and anastomose through a nearly impassible desert pavement that is comprised of tyre-eating sharp fragments of basaltic rock. After visiting the wadi on the south side of Jabal Bayda, the visitor is advised to either prepare a campsite, or turn back and retrace his route and return to the paved road leading back to Ath Thamad.

\section{Closing remarks}

In addition to the pure spirit of adventure and the chance to experience places that very few Geotourists have ever seen, the visitor will be rewarded with spectacular textbook examples of volcanic features that can be used for teaching elementary Geology. The archeology of the area captures a snapshot of Neolithic life and its main industry, and perhaps makes us feel grateful that the Neolithic period has come to an end (but its end was not due to the fact that they ran out of stones). Today, a trip to Al-Madinah no longer invokes images from an Agatha Christie novel. The modern Geotourist can fly to Al-Madinah International Airport on a daily service from Istanbul provided by one of the popular European airlines, and make a weekend trip to see geological features that are unique on the world stage.

\section{References}

Grainger D., 2007. The White Volcanoes. In: Grainger D. (ed.), The Geologic Evolution of Saudi Arabia. A Voyage Through Space and Time. Jeddah: Saudi Geological Survey, 37-46. 